\section{Sławomir Jan Stasiak}

Papieski Wydział Teologiczny we Wrocławiu gimel@poczta.onet.pl

ORCID: 0000-0002-0949-2043

DOI: http://dx.doi.org/10.12775/BPTh.2018.012
Biblica

et

Patristica

Thoruniensia

11 (2018) 2: 269-289

ISSN (print) 1689-5150

ISSN (online) 2450-7059

\title{
Sprawiedliwość Boża a usprawiedliwienie z wiary w Liście do Rzymian
}

\section{Justice of God and Justification by faith in Romans}

Streszczenie. Na podstawie występowania terminów hē dikaiosynē i dikaioō w Liście do Rzymian odkryliśmy, że teksty je zawierające tworzą interesujący układ. Pozwolił on nam na uporządkowanie materiału w ten sposób, że wyłoniła się dość uporządkowana wiedza na temat zarówno Bożej sprawiedliwości, jak i usprawiedliwienia, którego dostępuje chrześcijanin dzięki wierze w Jezusa Chrystusa. Przede wszystkim Paweł miał doskonałą świadomość jednej z podstawowych zasad judaizmu, którą przytoczył w Rz 2,13: „ci, którzy praktykują Prawo, zostaną usprawiedliwieni”. Jednak z całą pewnością nie identyfikował się z tym założeniem, a jedynie przytoczył tekst Starego Testamentu, aby następnie wykazać, że rzecz ma się zupełnie inaczej - człowiek zyskuje usprawiedliwienie przez wiarę, a na wzór Abrahama. Zagadnienie to dość obszernie omawia Apostoł w kolejnych rozdziałach listu. Wychodzi on od stwierdzenia faktu objawienia Bożej sprawiedliwości $(1,17)$. Ona staje się jeszcze bardziej jawna na tle naszej niesprawiedliwości ( $\mathrm{Rz} 3,3-5)$. Ma nadto wymiar historiozbawczy, prowadzący do sprawiedliwości każdego wierzącego. Boża sprawiedliwość skutkuje więc działaniami zbawczymi na rzecz człowieka, a podjął je Chrystus, umierając na krzyżu i zmartwychwstając. Wykład na ten temat Apostoł przeprowadził w 3,21-31, którego najkrótszym wnioskiem, a zarazem dowodzoną tezą jest to, że człowiek osiąga usprawiedliwienie z wiary w Jezusa Chrystusa, a nie na podstawie pełnienia uczynków wymaganych przez Prawo. Wszyscy mają w nim udział nie tylko Żydzi, dla których wiara jest continuum przez monoteizm religijny i przez udział w błogosławieństwie Boga, ale i poganie, na których wiara jest udziałem w zbawczej śmierci Chrystusa. Wzorem wiary, która skutkuje usprawiedliwieniem, jest Abraham, on bowiem uwierzył i to zostało mu policzone ku usprawiedliwieniu ( $\mathrm{Rz} 4,2-7)$. Odnotowaliśmy również, że usprawiedliwienie wierzącego niesie ze sobą bardzo konkretne skutki: trwanie w pokoju (Rz 5,1-2), zachowanie od gniewu Bożego ( $\mathrm{Rz}$ 5,9), wezwanie do unikania grzechów ( $\mathrm{Rz} 6,7$ ), obdarzenie chwałą (Rz 8,29-30.33). Mimo tak wielkich darów człowiek może wybrać drogę własnej sprawiedliwości, odrzucając Bożą sprawiedliwość, podobnie jak Izraelici wybrali drogę pełnienia uczynków wymaganych przez Prawo, a odrzucili wiarę w Jezusa Chrystusa i Jego Ewangelię. 
Abstract. Based on the occurrence of hè dikaiosynē and dikaioō in Romans we discovered that the texts constitute an interesting arrangement. He allowed us to organize the material in such a way that a fairly ordered knowledge of God's righteousness and the justification that the Christian has access to through faith in Jesus Christ emerged. Primarily, Paul was well acquainted with one of the basic principles of Judaism, which he quoted in Rom 2:13: “...the doers of the law who will be justified”. But he certainly did not identify with this premise, and merely quoted the text of the Old Testament to show that the thing was quite different - a man is justified by faith, like Abraham's. This issue is discussed extensively by Apostle in the subsequent chapters. He begins by stating the fact of the revelation of divine justice (1:17), which becomes even more evident in the context of our injustice (Rom 3:3-5). There is also a historical-saving dimension, leading to the justice of every believer. God's justice thus results in salvation for the sake of man, and Christ has taken up his dying on the cross and resurrected. The Apostle gave a lecture on this subject $\mathrm{w}$ 3:21-31, and the shortest conclusion, and at the same time, the thesis is that man is justified by faith in Jesus Christ, and not by the works required by the Law. Not only are the Jews involved, whose faith is the continuum of religious monotheism and participation in the blessing of God, but also the pagans on whom faith is involved in the saving death of Christ. The pattern of faith that results in the justification is Abraham, he believed and it was counted to him as righteousness (Rom 4:2-7). We also noted that the justification for the believer has very concrete consequences: to remain in peace (Rom 5:1-2), be saved from the wrath of God (Rom 5:9), to be set free from sin (Rom 6:7), giving glory (8:29-30.33). Despite such great gifts, a man can choose his own righteousness and rejecting God's righteousness, just as the Israelites chose the way of doing the works required by the law, and rejected faith in Jesus Christ and his Gospel.

Słowa kluczowe: św. Paweł; List do Rzymian; usprawiedliwienie; Prawo Mojżeszowe; Abraham.

Keywords: St. Paul; Romans; Justification; Mosaic Law; Abraham.

W iele już napisano na temat usprawiedliwienia w Liście do Rzymian¹. Zwykle jednak skupiano się albo na przedstawieniu kwestii usprawiedliwienia przez wiarę, a nie na podstawie uczynków wymaganych przez Prawo, albo na omawianiu tematu usprawiedliwienia w poszczególnych rozdziałach lub sekcjach listu. W niniejszym opracowaniu jako fundament metodyczny przyjęto występowanie w liście rzeczownika he dikaiosyne i czasownika dikaioō. Po wstępnych badaniach okazało się, że mamy do czynienia z cztere-

1 Zob. np. S. Westerholm, Justification by Faith is the Answer. What is the Question?, s. 197-217; L. Siwecki, Dobre uczynki usprawiedliwionego, s. 84-98; N.T. Wright, Justification by (Covenant) Faith to the (Covenantal) Doers, s. 95-108. 
ma przestrzeniami funkcjonowania tej terminologii. Przede wszystkim Paweł przypomina jedno z najważniejszych założeń judaizmu - Prawo jako święte prowadzi do sprawiedliwości (1). Samo jednak usprawiedliwienie dokonuje się przez wiarę w Jezusa Chrystusa, a wzorem jest Abraham, ojciec wszystkich wierzących (2). Usprawiedliwienie niesie ze sobą określone skutki, które zostały zaprezentowane przez Pawła nie w formie systematycznego wykładu, lecz jakby przy okazji omawiania poszczególnych aspektów Bożej sprawiedliwości i usprawiedliwienia człowieka (3). Człowiek jednak pozostaje wolny i może odrzucić Bożą sprawiedliwość, wybierając własną, podobnie jak to uczynili Izraelici, odrzucając wiarę w Jezusa Chrystusa i Jego Ewangelię (4). Rzecz jasna niniejsze opracowanie nie pretenduje do bycia systematycznym wykładem na temat Bożej sprawiedliwości i usprawiedliwienia z wiary w Liście Rzymian. Stanowi jedynie przyczynek do uporządkowania nauki przekazywanej na ten temat przez św. Pawła.

\section{Czy Prawo usprawiedliwia?}

Przekonanie wyznawców judaizmu, że uczynki wymagane przez Prawo dają usprawiedliwienie opierało się na jednym zasadniczym argumencie. Prawo jako dane przez Boga było święte, a zatem zachowanie wymaganych przez nie przepisów prowadziło do świętości, a więc także usprawiedliwienia. To przekonanie wydaje się potwierdzać Paweł, kiedy pisze na temat bezstronności Boga i konkluduje: „Bowiem nie ci, którzy słuchają Prawa są sprawiedliwi (dikaioi) przed Bogiem, lecz ci, którzy praktykują Prawo zostaną usprawiedliwieni (dikaiōthēsontai)" ( $\mathbf{R z} \mathbf{2 , 1 3})$. Słowa te zdają się wskazywać na podstawową zasadę judaizmu, tym bardziej że czasownik poiēo, jako tłumaczenie hebr. 'āśāh, w LXX jest używany w relacji do Prawa. Jednak Paweł tworzy tu swoistą opozycję pomiędzy słuchaniem (hoi akroatai) a praktykowaniem (hoi poiētai) Prawa, co mogłoby się sprzeciwiać nakazowi danemu Izraelowi: „Słuchaj (šema') Izraelu, JHWH jest twoim Bogiem, JHWH Jedynie" (Pwt 6,4; por. Pwt 4,1; 5,1). Na innych miejscach Starego Testamentu spotykamy zestawienie słuchania i praktykowania w odniesieniu do Prawa: „Wszystko, co powiedział Pan, uczynimy (na äśéh / poiēsomen) i będziemy słuchali ( $w^{e} n i s ̌ m a \bar{a}^{\prime} /$ kai akousometha)" (Wj 24,7). W rzeczywistości bowiem tylko Prawo, które jest słuchane, a jednocześnie praktykowane spełnia swoje zadanie: „Będziecie przestrzegać moich ustaw i moich wyroków. Człowiek, który je wypełnia, żyje dzięki nim” (Kpł 18,5). Czy jednak Paweł przytoczył tylko podstawową zasadę judaizmu, czy też identyfikował się z nią? Jak się wydaje Apostoł, podobnie jak w innych miejscach listu (zob. np. Rz 10,5; Ga 3,12), cytuje Stary Testament, aby następnie 
wykazać, że usprawiedliwienie osiąga się nie przez praktykowanie przepisów Prawa, lecz przez wiarę w Jezusa Chrystusa ${ }^{2}$. W Rz 2,13 można nawet dopatrzeć się zdecydowanej krytyki postawy wyznawców judaizmu, którzy z natury rzeczy powinni nie tylko słuchać Prawa, lecz także je praktykować. Tymczasem nie robią ani jednego, ani drugiego, co zresztą także na innym miejscu Paweł im wypominał: „Natomiast na tych wszystkich, którzy polegają na uczynkach wymaganych przez Prawo, ciąży przekleństwo. Napisane jest bowiem: Przeklęty każdy, kto nie wypełnia wytrwale wszystkiego, co nakazuje wykonać Księga Prawa" (Ga 3,10). Prawda ta wpisuje się również w nauczanie Jezusa: nie ci, którzy tylko słuchają Słowa Bożego będą zbawieni, lecz ci, którzy wprowadzają je w życie (por. Łk 8,21) ${ }^{3}$.

\section{Usprawiedliwienie z wiary na wzór Abrahama}

Proces usprawiedliwienia z wiary w Jezusa Chrystusa opiera się na sprawiedliwości Boga (hē dikaiosynē tou Theou). Jego typem jest Abraham, który uwierzył i zostało mu to poczytane za sprawiedliwość.

\subsection{Sprawiedliwość Boga}

Pisząc na temat Ewangelii, Paweł zauważa, że w niej „została objawiona sprawiedliwość Boga (dikaiosynē tou Theou), która $\mathrm{z}$ wiary wychodzi, ku wierze prowadzi, tak, jak zostało napisane: sprawiedliwy z wiary żyć będzie" (Rz 1,17). Aby dojść do właściwego rozumienia zwrotu dikaiosynē tou Theou, należy odpowiedzieć na pytanie: jaki charakter ma użyty tu Genetivus? W historii interpretacji uważano, że oznacza on sprawiedliwość, która jest atrybutem Boga i którą On rozdziela w sensie odpłaty za czyny człowieka. Jej zaś znaczenie było przeciwstawiane miłosierdziu, szczególnie tam, gdzie jest mowa o sprawiedliwości każącej. Nie to jednak miał na myśli Paweł, kiedy pisał na temat Bożej sprawiedliwości ${ }^{4}$. W każdym razie ten Genetivus ma charakter obiektywny i wskazuje na podmiot działania (Blass, Debrunner, Rehkopf ${ }^{5} \$ 163^{1}$ ). Bóg zatem jest źródłem sprawiedliwości, a ona została objawiona w Ewangelii. $\mathrm{Na}$ takie rozumienie pozwala inne miejsce, w którym Paweł pisze na temat sprawiedliwości Bożej: „On to dla nas Tego, który nie znał grzechu, uczynił grze-

2 Por. R. Penna, Lettera ai Romani, s. 154-155.

3 Por. S. Stasiak, Komentarz teologiczno-pastoralny, s. 265.

4 Por. J.A. Fitzmyer, Lettera ai Romani, s. 309.

5 F. Blass, A. Debrunner, F. Rehkopf, Grammatica del greco del Nuovo Testamento. 
chem, abyśmy się w Nim stali sprawiedliwością Bożą (dikaiosynē Theou)" (2 Kor 5,21). Stan, do którego zostaliśmy podniesieni dzięki Chrystusowi, stanowi dar pochodzący od Boga Ojca. W tym jednak przypadku moglibyśmy mówić także o Genetivie autora albo pochodzenia. W takim znaczeniu zwrot ten pojawia się jeszcze w Flp 3,18-19: „Z Jego (Chrystusa) powodu wszystko poczytuję za nic i uważam za śmieci, aby zyskać Chrystusa i zjednoczyć się z Nim - nie dzięki mojej sprawiedliwości wynikającej z Prawa (emēn dikaiosynēn tēn ek nomou), lecz dzięki sprawiedliwości osiągniętej przez wiarę w Chrystusa (tēn dia pisteōs Christou), sprawiedliwości z Boga na podstawie wiary" (ten ek Theou dikaiōsynen epi tē(i) pistei). Dopełnienie w formie przymiotnikowej (epi tēe(i) pistei) dobitnie świadczy o tym, że nie chodzi o prosty Genetivus ${ }^{6}$. W zwrocie dikaiosynē tou Theou, użytym przez Pawła w Rz 1,17 chodzi o Boga, który jest źródłem sprawiedliwości, a udziela jej dzięki wierze w Jezusa Chrystusa: „Jeśli bowiem z powodu przestępstwa jednego człowieka śmierć zaczęła królować z powodu tego jednego, to o ile bardziej ci, którzy otrzymują obfitość łaski i dar usprawiedliwienia (tēn dōreas tēs dikaiosynēs) będą królowali w życiu z powodu jednego, Jezusa Chrystusa" (Rz 5.17).

Bóg pozostaje wierny swoim słowom i obietnicom: „Cóż zatem, jeśli niektórzy nie uwierzyli? Czy ich niewiara udaremni wierność Boga? Nigdy to się nie stanie! Bóg bowiem musi okazać się prawdomówny, każdy zaś człowiek jest kłamcą, jak jest napisane: «Abyś się okazał sprawiedliwy w swoich słowach (an dikaiōthè (i)s en tois logois), a zwyciężysz, gdy będziesz sądzony». Jeśli więc nasza niesprawiedliwość uwydatnia sprawiedliwość Boga (Theou dikaiosynēn), cóż powiemy? Czyż Bóg jest niesprawiedliwy, objawiając gniew? Mówię po ludzku" (Rz 3,3-5). Powraca tu ten sam zwrot, co w poprzednim tekście z tą jednak różnicą, że mamy do czynienia z konwersją pojęć: Theou dikaiosynē. Jest to niewątpliwie wyrażenie typowo Pawłowe o charakterze pozytywnym. Kontekst wypowiedzi niesie ze sobą dwie analogiczne konstrukcje, których wymiar pozytywnie soteriologiczny jest poza dyskusją. Pierwszą z nich jest przeciwstawienie niewierności ludzi wierności Boga (w. 3). Druga to przeciwstawienie prawdy Bożej kłamstwu (w. 7). W ten sposób utworzona została syntagma składająca się z odpowiadających sobie pojęć negatywnych (hē apistia, w. 3; he adikia, w. 5; to pseusma, w. 7) i pozytywnych (he pistis tou Theou, w. 3; Theou dikaiosyne, w. 5; he aletheia tou Theou, w. 7). W ten sposób, bez wątpienia zwrot Theou dikaiosyne stanowi wyrażenie synonimiczne do dwóch pozostałych ${ }^{7}$. Paweł jednak nie chce powiedzieć, że Bóg chce ujawnić naszą niesprawiedliwość, lecz raczej, że nasza niesprawiedliwość ujawnia jeszcze bardziej Bożą

6 Por. J.A. Fitzmyer, Lettera ai Romani, s. 310.

7 Por. R. Penna, Lettera ai Romani, s. 201. 
sprawiedliwość, analogicznie do tego, co zostało powiedziane przez Apostoła w Rz 5,20-21: „Prawo zaś weszło, aby pomnożyło się przestępstwo. Gdzie zaś pomnożył się grzech, tam w nadmiarze zaobfitowała łaska, aby jak grzech zakrólował przez śmierć, tak też łaska zakrólowała przez sprawiedliwość (dia dikaiosynēs eis dzōèn aiōnion), która prowadzi do życia wiecznego przez Jezusa Chrystusa, Pana naszego”. Zatem „Boża sprawiedliwość” (Theou dikaiosynē) nie tylko ujawnia się jeszcze bardziej na tle niesprawiedliwości człowieka, lecz przede wszystkim ma charakter historiozbawczy. Zatem Bóg nie chce, by Jego sprawiedliwość ujawniła się na tle grzechów popełnianych przez człowieka.

\subsection{Usprawiedliwienie z wiary w Jezusa Chrystusa}

Sprawiedliwość Boga skutkuje działaniami zbawczymi na rzecz człowieka, które podjął Jezus Chrystus umierając na krzyżu i zmartwychwstając. Człowiek jednak musi w niego uwierzyć, co Paweł zawarł w prostej sentencji: „Wiemy jednak, że człowiek nie dostępuje usprawiedliwienia z uczynków Prawa, lecz przez wiarę w Jezusa Chrystusa" (Ga 2,16). Zagadnienie to znacznie szerzej omawia w Liście do Rzymian, a szczególnie w Rz 3,21-30. Wypowiedź poprzedniej sekcji (3,19-20), kończy się stwierdzeniem: z uczynków Prawa nikt nie zostanie usprawiedliwiony (dikaiōthēsetai) przed Nim, bowiem przez Prawo przychodzi poznanie grzechu ( $\mathrm{Rz} 3,20)$. Wezwanie do milczenia („aby każde usta zamilkły"; w. 19) ma swoje źródło w Prawie. Z jednej strony pozostaje ono bezsilne w sprawie usprawiedliwienia, $\mathrm{z}$ drugiej zaś strony, jest dobrodziejstwem, ponieważ przez nie człowiek może lepiej i pełniej uświadomić sobie wielkość swoich grzechów.

Teraz następuje pozytywny niemalże wykład dotyczący usprawiedliwienia przez wiarę w Jezusa Chrystusa, a nie przez uczynki wymagane przez Prawo. Wypowiedź rozpoczyna się od propositio: „Teraz zaś niezależnie od Prawa jawną okazała się sprawiedliwość Boga (dikaiosynē Theou) poświadczana przez Prawo i Proroków, sprawiedliwość Boga (dikaiosynē de Theou) przez wiarę w Jezusa Chrystusa, dla wszystkich wierzących." (Rz 3,21-22a). Sprawiedliwość Boża, będąca przeciwieństwem Bożego gniewu, objawiła się w czasie. Jak już wspomnieliśmy wyżej, nie chodzi o wymiar jurydyczny pojęcia dikaiosynē Theou, lecz raczej o synonim wierności (por. Rz 3,3) i prawdy Bożej (por. Rz 3,7), Jego miłości i miłosierdzia, które zostały dane ludzkości pogrążonej w grzechach. Dzięki tej sprawiedliwości wierzący zyskują udział w świętości samego Boga, to jest właśnie istota usprawiedliwienia, które nie wiąże się w żaden sposób z przestrzeganiem przepisów wymaganych przez Prawo. Posiada jednak zasadniczy związek $\mathrm{z}$ wiarą $\mathrm{w}$ Jezusa Chrystusa. Jest to podstawowa i zasadnicza teraz Listu do Rzymian. Ma ona niewątpliwie charakter polemicz- 
ny ${ }^{8}$, Apostoł bowiem odpowiada w ten sposób tym chrześcijanom, którzy mogli uważać, że mimo zbawczego dzieła Jezusa Chrystusa, nadal konieczne jest pełnienie uczynków wynikających z Prawa. W opinii Pawła nie jest to absolutnie konieczne, wystarczy wiara w Jezusa Chrystusa, czyli całkowite „tak” wobec zbawczego dzieła Jezusa Chrystusa, całkowite zaufanie Mu i wejście w osobową relację z Nim. Usprawiedliwienie więc dokonuje się dia pisteōs Iēsou Christou?.

Jeśli chodzi o możliwość zyskania usprawiedliwienia, to decyduje jedynie wiara w Jezusa Chrystusa. Nie ma tu żadnych preferencji, ani narodowych, ani religijnych: „Nie ma bowiem różnicy, wszyscy bowiem zgrzeszyli i pozbawieni są chwały Boga, a usprawiedliwieni są darmo (dikaioumenoi dōrean), Jego łaską, przez odkupienie w Chrystusie Jezusie" (Rz 3,22b-24). Nie chodzi w tym opracowaniu o prezentację wszystkich zagadnień teologicznych zawartych $\mathrm{w}$ tej wypowiedzi, a jedynie o skupienie się na usprawiedliwieniu. Paweł po raz kolejny posługuje się czasownikiem dikaioō, który spotkamy wcześniej już trzykrotnie $(2,13 ; 3,4.20)$. Tam oznaczał ,jestem uznany za sprawiedliwego" $(2,16 ; 3,20)$ lub „okazuję się sprawiedliwy w wyniku procesu” $(3,4)$. Takie znaczenie w naszym tekście jest niemożliwe, bowiem tu chodzi o zmianę stanu człowieka, czyli przejście od grzechu do chwały, która jest pierwotnym, właściwym stanem człowieka. W naszym kontekście dikaioō stoi w opozycji do hamartanō i do hysterountai tēs doksēs tou Theou. Dzięki usprawiedliwieniu chwała Boża powraca do tego, kto zgrzeszył. Akt usprawiedliwienia jest wydarzeniem, które aktualizuje się dla wierzącego przez wiarę (por. 3,22), o którym zostało powiedziane, że przez nią właśnie będzie miał udział w sprawiedliwości Bożej. Zatem „być uznanym za sprawiedliwego”, to znaczy stać się uczestnikiem sprawiedliwości Bożej dzięki wierze w Jezusa Chrystusa. Ten, kto został usprawiedliwiony (dikaioumenos), to człowiek, dla którego przez wiarę dotarła sprawiedliwość Boża (diakiosynē Theou) ${ }^{10}$. Paweł jest konsekwentny w prezentacji usprawiedliwienia jako rzeczywistości niezależnej od zasług człowieka osiąganych przez pełnienie uczynków wymaganych przez Prawo. Teraz stwierdza, że usprawiedliwienie zyskuje się w sposób całkowicie darmowy (dikaioumenoi dōrean). Paweł w żadnej innej wypowiedzi nie wiąże tego przysłówka z usprawiedliwieniem. Jedynie w Liście do Galatów, tam jednak wypowiedź ma inny kontekst: „Jeżeli zaś usprawiedliwienie dokonuje się przez Prawo, to

8 Zob. S. Stasiak, Komentarz teologiczno-pastoralny, 273.

9 Taką opinię wyraża także Katechizm Kościoła Katolickiego: „Łaska Ducha Świętego ma moc usprawiedliwić nas, to znaczy obmyć nas z naszych grzechów i udzielić nam «sprawiedliwości Bożej przez wiarę w Jezusa Chrystusa»(Rz 3,22) i przez chrzest"; Katechizm Kościoła Katolickiego, Poznań 1994.

10 Por. H. Schlier, La lettera ai Romani, s. 192. 
Chrystus umarł na darmo (dōrean apethanen)" (Ga 2,21). Zatem usprawiedliwienie zostało darowane wierzącym bez żadnych ich zasług. Wypowiedź Apostoła w tej materii staje się jeszcze mocniejsza przez podkreślenie, że usprawiedliwienie dokonało się pod wpływem działania łaski Boga (tè(i) autou chariti). Użyty tu Dativus wskazuje na sposób, w jaki dokonało się usprawiedliwienie. Łaska jest jednym z głównych tematów teologii Pawła w ogólności, a Listu do Rzymian w szczególności, o czym świadczy użycie rzeczownika hē charis (22 razy w Rz). W naszym kontekście oznacza on nie tylko darmo darowany dar, lecz zyskuje wymiar zdecydowanie teologiczny. Rzecz dotyczy nowej ekonomii łaski, pochodzącej i opierającej się na miłości i miłosierdziu Boga $\mathrm{Ojca}^{11}$. Działanie łaski dokonuje się przez odkupienie w Chrystusie Jezusie (dia tès en Christō(i) Iēsou). Stwierdzenie to jeszcze mocniej podkreśla fakt, że akt usprawiedliwienia dokonał się poza przestrzenią oddziaływania wierzącego, jakkolwiek rzeczownik he apolytrōsis, który wskazuje akt wykupienia przez uiszczenie odpowiedniej opłaty celem wyzwolenia niewolnika ${ }^{12}$. W naszym kontekście Paweł nie wspomina, kiedy dokonuje się odkupienie w Chrystusie Jezusie, czy w czasie przeszłym przez Jego śmierć, czy w czasie obecnym przez wiarę w Niego. W rzeczywistości bowiem wyrażenie może wskazywać na czas teraźniejszy, jak w 1 Kor 1,30: „Przez Niego bowiem jesteście w Chrystusie Jezusie, który stał się dla nas mądrością od Boga i sprawiedliwością, i uświęceniem, i odkupieniem (apolytrōsis)". Oczywiście nie chodzi o kwestionowanie historycznego aktu odkupienia dokonanego przez śmierć Chrystusa, o czym będzie mowa w kolejnych wersetach, teraz jednak chce wyraźnie podkreślić, że darmowe usprawiedliwienie przez łaskę Boga dokonuje się teraz (nyni de; w. 21) przez wiarę w odkupieńcze dzieło Chrystusa Jezusa.

W kolejnych słowach Apostoł wyjaśnia, na czym polega proces działania sprawiedliwości Boga, okazanej wierzącym przez zbawcze dzieło Jezus Chrystusa: „Jego ustanowił Bóg narzędziem przebłagania przez wiarę, w Jego krwi, aby ukazać swoją sprawiedliwość (tēs dikaiosynēs autou) przez odpuszczenie grzechów, które zostały popełnione wcześniej, w czasie cierpliwości Bożej, i aby ukazać swoją sprawiedliwość (tēs dikaiosynēs autou) w teraźniejszym czasie, aby się okazało, że On jest sprawiedliwy i usprawiedliwia tego, kto wierzy w Jezusa (dikaiounta ton ek pisteōs Iēsou)" (Rz 3,25-26). Aby sprawiedliwość Boża została ukazana, On sam ustanowił Jezusa narzędziem przebłagania. Komentatorzy tego tekstu zwykle opierają swoje wnioski na temat pojęcia hilastêrion na bezpośrednim kontekście wypowiedzi Apostoła $\mathrm{z}$ aluzjami do rytuału ofiar

11 Por. J.A. Fitzmyer, Lettera ai Romani, s. 417.

12 Por. R. Penna, Lettera ai Romani, s. 252-253. 
w judaizmie oraz na znaczeniu czasowników ilasthesthai i eksilasthesthai ${ }^{13}$. Należy jednak pamiętać, że $w$ innych tekstach starożytnych niż $R z$ 3,25, hilastērion nigdy nie oznacza ani idei, ani działania, ani człowieka. Zatem użycie tego pojęcia w tym tekście musi mieć charakter metaforyczny ${ }^{14}$. W kontekście Rz 3,25 hilastērion to Accusativus, który może pochodzić zarówno od rzeczownika to hilastērion („ofiara przebłagalna, dar przebłagalny”), jak i od przymiotnika hilastērios, - $a$, -on („przebłagalny, pojednawczy”) ${ }^{15}$, który występowałby tu w znaczeniu rzeczownikowym na określenie tego, który dokonuje przebłagania. Jeśli byłby to rzeczownik, to Chrystus jest narzędziem przebłagania, albo miejscem przebłagania, a jeśli przymiotnik, to Bóg przedstawia Chrystusa jako Tego, który dokonuje przebłagania. Zatem Chrystus jest nowym „miejscem” działania Bożego miłosierdzia, dzięki któremu dokonany został akt przebłagania za grzechy ludzkości. Chrystus jest więc „miejscem” przebywania Boga, objawienia się Jego sprawiedliwości ${ }^{16}$. Ustanowienie Chrystusa narzędziem przebłagania dokonało się przez wiarę (dia tēs pisteōs) tego, który dzięki niej ma udział w owocach zbawczego Jego dzieła, a jego celem ujawnienie się sprawiedliwości Bożej. Jakie jednak ma znaczenie użyte tu określenie tēs dikaiosynēs autou? Czy chodzi o atrybut Boga? D. Burk wyklucza autou jako Genetivus abiectivus lub subiectivus. Jest raczej zdania, za E. Käsemannem ${ }^{17}$, że mógłby to być Genetivus źródła i wskazuje, w jaki sposób zwrot ten, właśnie w takim znaczeniu, funkcjonuje w innych fragmentach Listu do Rzymian ${ }^{18}$. Zatem dzięki wierze w Chrystusa Bóg pozwala grzesznemu człowiekowi, by miał w Jego sprawiedliwości ukazanej przez śmierć Jezusa Chrystusa. Paweł w bardzo zwięzłych słowach opisuje stan usprawiedliwionego chrześcijanina: ton ek pisteōs Ièsou; dosł.: „tego, kto przez wiarę w Chrystusa” (w. 26). On właśnie staje się członkiem Chrystusa i żyje nowym życiem w Nim. Sprawiedliwość ta nie jest

13 Zob. np. S. Schreiber, Das Weihegeschenk Gottes: eine Deutung des Todes Jesu in Röm 3,25, s. 88-110; J.D.K. Ekem, A Dialogical Exegesis of Romans 3.25a, s. 75-93; C.T. Holmes, Utterly Incapacitated. The Neglected Meaning of $\pi \alpha \dot{\alpha} \rho \sigma \iota \varsigma$ in Romans 3:25, s. 349-366; A. Weiss, Christus Jesus als Weihegeschenk oder Sühnemal?, s. 294-302; M.W. Wilson, Hilasterion and Imperial Ideology. A New Reading of Romans 3:25, s. 1-9.

14 D.P. Bailey, Jesus as the Mercy Seat. The Semantics and Theology of Paul's Use of hilasterion in Romans 3:25, s. 155.

15 Z. Abramowiczówna, Słownik grecko-polski, t. II, s. 500.

16 Tak J.A. Fitzmyer, Lettera ai Romani, s. 418-419.

17 E. Käsemann, Commentary on Romans, s. 100.

18 D. Burk, The righteousness of God (Dikaiosunē Theou) and Verbal Genitives. A Grammatical Clarification, s. 346-360. 
już prawością osiągniętą dzięki przestrzeganiu przepisów Prawa, lecz dokonuje się ek pisteōs, to znaczy „za pośrednictwem wiary w Jezusa”19.

Paweł w ten sposób podsumowuje ten swoisty wykład na temat usprawiedliwienia przez wiarę w Jezusa Chrystusa: „Gdzie jest więc powód do chluby? Został usunięty. Przez jakie prawo? Uczynków? Nie, lecz przez prawo wiary. Uważamy bowiem, że człowiek jest usprawiedliwiony przez wiarę (logidzometha gar dikaiousthai pistei anthrōpon), niezależnie od uczynków Prawa. Czy Bóg jest jedynie Bogiem Żydów? Czy także i pogan? Tak, także i pogan. Przecież jeden jest Bóg, który usprawiedliwia (heis ho Theos hos dikaiōsei) obrzezanych w wierze, a nieobrzezanych przez wiarę" (Rz 3,27-30). Konsekwencją usprawiedliwienia przez wiarę, niezależnie od uczynków Prawa jest udział w nim nie tylko Żydów „w wierze” (ek pisteōs), lecz także pogan „przez wiarę” (dia tēs pisteōs). Wprawdzie przyimki ek i dia mogą mieć znaczenie synonimiczne, Paweł bowiem zna takie ich użycie (zob. np. Rz 4,11; 5,10; 1Kor 12,8; 2 Kor 3,11$)^{20}$, jednak wówczas zastanawiąący byłby fakt dlaczego Apostoł miałby użyć różnych przyimków, skoro chciał wyrazić tę samą relację do wiary. Bardziej więc prawdopodobną wydaje się możliwość, że Paweł posłużył się nimi dla odróżnienia stosunku do wiary Żydów (ek) i pogan (dia). Dla pierwszych wiara byłaby swoistym continuum, nie tylko ze względu na ten sam monoteizm religijny, lecz także ze względu na udział w błogosławieństwie Bożym i Jego obietnicach, które nigdy nie zostały odwołane. Dla drugich wiara byłaby udziałem w zbawczej śmierci Jezusa Chrystusa ${ }^{21}$.

\subsection{Na wzór Abrahama}

Kluczem do zrozumienia kolejnej wypowiedzi (Rz 4,1-7) jest cytat $\operatorname{Rdz} 15,6$ za LXX, który zawiera tezę przedstawioną już wcześniej w sensie ogólnym (Rz 3,21-26.28), a tutaj z odwołaniem do konkretnej postaci Starego Testamentu: usprawiedliwienie Abrahama było owocem jego wiary ${ }^{22}$. Tak brzmi w całości wypowiedź Apostoła: „Jeśli (ei) bowiem Abraham został usprawiedliwiony dzięki uczynkom (eks ergōn edikaiōthē), ma powód do chluby, lecz nie przed Bogiem. Co bowiem mówi Pismo? Uwierzył (episteusen) zaś Abraham Bogu i policzone mu to zostało ku usprawiedliwieniu (eis dikaiosynēn). Pracującemu zaś zapłata nie jest liczona według łaski, lecz według należności. Niepracują-

\footnotetext{
19 Por. J.A. Fitzmyer, Lettera ai Romani, s. 423.

20 A. Pitta, Lettera ai Romani, s. 180.

21 K. Romaniuk, List do Rzymian, s. 122; J.A. Fitzmyer, Lettera ai Romani, s. 437.

22 Taką tezę wyciągnąłem już we wcześniejszej publikacji: zob. S. Stasiak, Komentarz teologiczno-pastoralny, s. 277.
} 
cemu zaś jednak wierzącemu w Tego, który usprawiedliwia (pisteuonti de epi ton dikaiounta) bezbożnego, wiara jest liczona ku usprawiedliwieniu (hē pistis autou eis dikaiosynēn). Tak jak i Dawid wypowiada pochwałę człowieka, któremu Bóg liczy usprawiedliwienie niezależnie od uczynków (dikaiosynēn chōris ergōn): Błogosławieni, których nieprawości zostały odpuszczone i których grzechy zostały ponownie zakryte" (Rz 4,2-7). Perykopa ta ma dość szczególną kompozycję:

A. Pozorne założenie (ei): Abraham został usprawiedliwiony dzięki uczynkom (w. 2);

B. Teza: Abraham uwierzył i to zostało mu poczytane ku usprawiedliwieniu (w. 3);

B' Dowód: wierzącemu w Tego, który usprawiedliwia, wiara jest liczona ku usprawiedliwieniu (w. 5);

A’. Wniosek (hathaper): Bóg usprawiedliwia człowieka niezależnie od uczynków (ww. 6-7).

Należy odnotować, że sekcje A i A' odpowiadają sobie w formie antytetycznej: eks ergōn edikaiōthē (w. 2) - dikaiosynēn chōris ergōn (w. 6); a sekcje centralne B i B' zdominowane zostały przez wypowiedzi łączące wiarę ze sprawiedliwością: episteusen... eis dikaiosynēn (w. 3), pisteuonti de epi ton dikaiounta (w. 5a), hē pistis autou eis dikaiosynēn (w. 5b). Apostoł przez dowodzenie tezy w centralnych wersetach sekcji prowadzi do obalenia pozornego założenia, a ostateczny wniosek jest następujący: Bóg usprawiedliwił tak Abrahama, jak i usprawiedliwia każdego człowieka, niezależnie od uczynków wymaganych przez Prawo, lecz dzięki wierze w Jezusa Chrystusa.

Pozorne założenie zostało wprowadzone partykułą ei. Paweł sugeruje możliwość, że Abraham mógł zostać usprawiedliwiony przed Bogiem dzięki swoim uczynkom. Syrach, posługując się swoistym midraszem do Rdz 26,5, wychwala patriarchę, ponieważ „on zachował prawo Najwyższego”, „a w doświadczeniu okazał się wierny” i „dlatego Bóg przysięgą zapewnił go, że w jego potomstwie będą błogosławione narody" (Syr 44,19-23). Podobnie współczesny Pawłowi judaizm idealizował postać i czyny Abrahama, wysuwając tezę, że doskonale zachowywał on Prawo Mojżesza, jeszcze zanim zostało ogłoszone. Zatem jego sprawiedliwość była przypisywana wierności i prawości, które okazały się kiedy został poddany próbie, a dokładniej wówczas, gdy polecono mu, aby złożył w ofierze swojego syna Izaaka ( $\operatorname{Rdz} 22,9-10)^{23}$. To byłyby te uczynki, dzięki którym Abraham został usprawiedliwiony (eks ergōn edikaiōthē). Po tym, co napisał w 3,21-31, Paweł nie mógł stwierdzić, że Abraham stanowi

23 Por. J.A. Fitzmyer, Lettera ai Romani, s. 445. 
wyjątek. Właśnie dlatego swoja argumentację opiera na Rdz 15,6. Zdanie więc rozpoczynające się od ei jest nierzeczywistym okresem hipotetycznym, który wyraża ideę przeciwną do rzeczywistości. Paweł zatem wypowiada się w sensie czysto teoretycznym ${ }^{24}$. Negatywną ocenę wysuniętego przez Pawła pozornego założenia potwierdza również końcowe stwierdzenie wersetu (all' ou pros Theon). Można byłoby przypuszczać, że Abraham może się chlubić przed innymi ludźmi, ale nie przed Bogiem ${ }^{25}$. To jednak byłby jedynie przyczynek do teoretycznej dyskusji, a nie do rzeczywistego stanu rzeczy. W ten sposób Paweł przechodzi od prezentacji nierzeczywistej hipotezy do przedstawienia rzeczywistego stanu rzeczy. W rzeczywistym świecie działania Bożego w Chrystusie (Rz 3,21-26) nikt nie może się chlubićc ${ }^{26}$.

Przedstawione wyżej nierzeczywiste zdanie hipotetyczne zyskuje wyjaśnienie i argument biblijny w przywołanym przez Pawła cytacie na temat wiary Abrahama, która została mu poczytana za sprawiedliwość. Jest to pierwsza z wypowiedzi łączących pojęcia „wiary” i „sprawiedliwości”. Spotykamy tu jeszcze jeden czasownik (logidzomai), który w dalszej części argumentacji (ww. 5-6) odegra znacząca rolę. Dotąd Paweł odwoływał się przede wszystkim do sprawiedliwości Boga (hē dikaiosynē Theou; zob. 1,17; 3,5.21.22.25.26). Teraz akcent zostaje postawiony na stan człowieka w świetle tego, co Apostoł napisał wcześniej: „wszyscy... usprawiedliwieni są darmo” $(3,23-24)$ i „człowiek jest usprawiedliwiony przez wiarę" $(3,28)$. Tłem i podstawą pojęcia sprawiedliwości jest idea doskonałych wzajemnych relacji, a zatem pełna wzajemna komunikacja $^{27}$. W swoim użyciu i interpretacji Rdz 15,6 Paweł nie tylko zdecydowanie akcentuje przeciwstawienie roli wiary i uczynków wymaganych przez Prawo. W tym fragmencie Starego Testamentu nie widzi ani idei zasługi ze strony Abrahama, ani odpłaty ze strony Boga. W konsekwencji więc wskazuje, że źródłem usprawiedliwienia Abrahama była wiara.

W dalszej części Paweł nawiązuje do tezy i podaje argumenty oparte na normalnych zobowiązaniach kontraktowych dotyczących pracodawcy i pracownika. Wykazuje jednak, że w odniesieniu do wiary nie mają one zastosowania: „Niepracującemu zaś jednak wierzącemu w Tego, który usprawiedliwia bezbożnego, wiara jest liczona ku usprawiedliwieniu” (w. 5). Gra słów pomię-

24 Por. J. Lambrecht, Why is Boasting Excluded? A Note on Rom 3:27 and 4:2, s. 365369; R. Penna, Lettera ai Romani, s. 292.

25 Taką hipotezę przypomina K. Romaniuk, List do Rzymian, s. 123.

26 J. Lambrecht, R.W. Thompson, Justification by Faith, s. 74-77; R. Penna, Lettera ai Romani, s. 292.

27 Tak L. Koehler, W. Baumgartner, J.J. Stamm, Wielki słownik hebrajsko-polski i aramejsko-polski Starego Testamentu, s. 84-85. 
dzy pojęciami „wiary” (pisteuō, hē pistis), „działania” (mē ergadzō) i „sprawiedliwości" (dikaiosynē) prowadzona jest przez Pawła nadal. Pierwszy i trzeci termin zostały po raz kolejny ze sobą połączone i przeciwstawione wykonywaniu dzieł wynikających z nakazów Prawa. Paweł zatem przeciwstawia wiarę pracy i odpowiadającej jej zapłacie. Usprawiedliwienie dotyczy sytuacji wiary, a nie pracy i zapłaty. Stwierdzenie epi ton dikaionta ton asebē nie oznacza, że Abraham był bezbożny zanim uwierzył w JHWH. Chodzi raczej o opis Boga: jest On Tym, „który usprawiedliwia bezbożnego”, przebacza grzesznikowi. Zatem również Abraham jest zależny od Boga, „który usprawiedliwia bezbożnego”. W ten sposób zaakcentowany został fakt, że inicjatywa usprawiedliwienia pochodzi od Boga, a nie od człowieka, od którego wymaga się jedynie wiary ${ }^{28}$. Bóg bowiem nie tylko akceptuje dobro, które ludzie mogą czynić, lecz także sam podejmuje inicjatywę przywrócenia właściwego stanu człowiekowi, który nie może zbawić samego siebie i prowadzi bezbożnych i grzeszników do stanu sprawiedliwości wobec siebie (por. Ga 2,16).

W kontekście kolejnej wypowiedzi („wiara jest liczona ku usprawiedliwieniu”; w. 5b), nie identyfikować „wierzącego” z „bezbożnym”, o którym była mowa wcześniej. Czasownik logidzetai, jak wspomnieliśmy już wyżej, wyraźnie nawiązuje do cytatu z Rdz 15,6 (w. 3). W ten sposób Paweł dokonuje syntezy swojej fundamentalnej tezy, odwołując się do przykładu Abrahama, który był uznany za sprawiedliwego przez Boga nie z powodu przestrzeganego Prawa, lecz dzięki wierze. Właśnie dlatego stał się on punktem zwrotnym w całej historii, a nie tylko narodu wybranego ${ }^{29}$.

Teraz Paweł przechodzi do przedstawienia ostatecznego wniosku przez przywołanie kolejnego cytatu. Tym razem jednak poprzedza go nie tylko wprowadzeniem (kathaper kai Dauid legei), lecz także komentarzem, który jest $\mathrm{z}$ jednej strony nawiązaniem do Rdz 15,6, a z drugiej strony stanowi interpretację cytowanego Ps 32,1-2 (LXX). Oba fragmenty łączy czasownik logidzomai. Taki rodzaj dowodzenia w literaturze rabinackiej zwie się gezerah šawah, to znaczy „jednakowe oznaczenie" 30 . Sama końcowa konkluzja zawarta we wprowadzeniu cytatu stanowi całkowite zaprzeczenie hipotetycznego założenia $\mathrm{z}$ w. 2, a brzmi następująco: „Bóg liczy usprawiedliwienie niezależnie od uczynków” (w. 6). Nie jest to jedynie wniosek z przeprowadzonego dowodzenia w sprawie wiary Abrahama, lecz także zasadnicza teza Listu do Rzymian.

28 Tak A. Pitta, Lettera ai Romani, s. 186.

29 Por. J.A. Fitzmyer, Lettera ai Romani, s. 449.

30 Szerzej na temat tego sposobu argumentowania w judaizmie zob. P. Basta, Gezerah Shawah. Storia, forme e metodi dell'analogia biblica. 


\section{Skutki usprawiedliwienia}

Paweł nie tylko omawia zagadnienie usprawiedliwienia, które dokonuje się przez wiarę, a nie przez uczynki wymagane przez Prawo, lecz także wskazuje jego skutki. Pierwszym z nich jest pokój (Rz 5,1), o który chrześcijanie mają dbać, aby zachować dostęp do łaski. To zaś skutkuje zachowaniem od karzącego gniewu Boga (Rz 5,9). Raz usprawiedliwieni chrześcijanie winni unikać okazji do grzechu (Rz 6,7.13), bo ten skutkuje śmiercią. Wybrani zaś i usprawiedliwieni są obdarzeni chwałą (Rz 8,30) i nikt nie może ich odłączyć od Tego, któremu zawdzięczają swoje wybranie (Rz 8,33). Ostatecznym celem każdego wierzącego jest królestwo Boże, ono jednak „nie jest pokarmem i napojem, ale sprawiedliwością, pokojem i radością w Duchu Świętym” (Rz 14,17). Te właśnie zagadnienia przedstawimy w niniejszym punkcie opracowania.

\subsection{Trwanie w pokoju}

Pierwszym skutkiem usprawiedliwienia jest pokój (hēe eirēnēe), rozumiany jako związek dwóch osób naznaczony zgodą: „Będąc więc usprawiedliwionymi z wiary (dikaiōthentes oun ek pisteōs), pokój mamy względem Boga przez Pana naszego, Jezusa Chrystusa, przez Niego mamy dostęp dzięki wierze do tej łaski, w której zostaliśmy utwierdzeni i chlubimy się w nadziei chwały Boga" (Rz 5,1-2). Problemem jest tu jednak czasownik, który wyraża działanie człowieka usprawiedliwionego wobec pokoju. W tradycji transmisji tekstu posiada on dwa warianty: echomen (indicativus) i echōmen (coniuntivus). Tak jedna, jak i druga lekcja są dobrze udokumentowane (zewnętrzne kryterium). Lektura w trybie oznajmującym kładzie nacisk na potwierdzenie faktu i lepiej ukazuje skutek usprawiedliwienia, co lepiej odpowiada całemu kontekstowi wypowiedzi. Jednak lekcja w coniunctive wprowadza swoisty akcent parenetyczny i jest nietypowa dla greki biblijnej i hellenistycznej. Byłby zatem lekcją trudniejszą, którą należałoby preferować. Nie ma jednak wystarczających argumentów do przyjęcia echōmen jako lekcji oryginalnej ${ }^{31}$. Myśl Pawła w tym kontekście raczej nie idzie w kierunku zachęty, lecz podkreśla owoc usprawiedliwienia, jakim jest pokój. O ile owocem grzechu jest niepokój i chaos, o tyle skutkiem usprawiedliwienia jest pokój ${ }^{32}$.

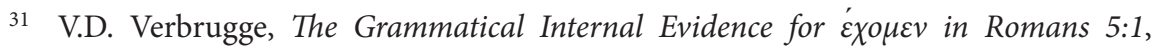
s. $570-572$.

32 Takie znaczenie wyrażenie dikaiōthentes oun ek pisteōs eirēnēn echomen zaproponowałem już w S. Stasiak, Komentarz teologiczno-pastoralny, s. 283. 


\subsection{Zachowanie od gniewu Bożego}

Niezbywalną konsekwencją usprawiedliwienia człowieka jest uchronienie go od Bożego gniewu: „Tym więc bardziej, będąc usprawiedliwionymi w Jego krwi (dikaiōthentes nyn en tō(i) haimati autou), zostaniemy zbawieni przez Niego od gniewu" (Rz 5,9). Wprawdzie usprawiedliwienie nie jest w tym kontekście pojęciem wiodącym, jednak to właśnie na nim opiera się ocalenie od sądu Bożego, takie bowiem ma znaczenie termin hè orgēe. Poza tym usprawiedliwienie ma swoje źródło we krwi Chrystusa, która stała się ceną, za jaką dokonało się odkupienie. Zatem odkupienie jawi się jako dar znacznie większy niż samo usprawiedliwienie. $\mathrm{W}$ ten sposób Apostoł wyciągnął wniosek $\mathrm{z}$ argumentacji przedstawionej w poprzednich wersetach $(5,1-8)$. W sensie formalnym usprawiedliwienie zostało podporządkowane odkupieniu. Dzięki usprawiedliwieniu we krwi Chrystusa dokona się zbawienie od gniewu, czyli od wyroku skazującego w czasie Sądu Ostatecznego. Niewykluczone, że w tym swoistym przeciwstawieniu krwi Chrystusa gniewowi Boga podjęta została starotestamentowa idea baranka paschalnego. Jego krew chroniła Izraelitów przed gniewem Boga, który spadł na Egipcjan (zob. Wj 12,1-14). Teraz zaś krew Chrystusa powstrzymuje gniew Boży nie tylko wobec Izraelitów, lecz także pogan ${ }^{33}$. Usprawiedliwienie przez krew Chrystusa wpisuje się w ten sposób w jeden $\mathrm{z}$ wiodących tematów teologii biblijnej Starego Testamentu.

\subsection{Unikanie grzechu}

Naturalną konsekwencją śmierci jest uwolnienie od grzechu: „Kto bowiem umarł, jest usprawiedliwiony (dedikaiōtai) od grzechu" ( $\mathbf{R z} 6,7)$. Jest to dość enigmatyczna wypowiedź, która zamyka dłuższą wypowiedź Pawła na temat wyzwolenia chrześcijanina z niewoli grzechu. Stwarza ona nieco trudności interpretacyjnych. Pierwsze pytanie, które się nasuwa, to: czy śmierć, o której tu mowa, ma znaczenie dosłowne czy metaforyczne? Kontekst poprzedzający wskazywałby raczej na to drugie znaczenie, ponieważ śmierć jest metaforą wyzwolenia z niewoli grzechu, a więc radykalnej odnowy życia człowieka ${ }^{34}$. Ostatecznie na znaczenie wskazuje kontekst. Jeśli śmierć fizyczna stanowi wyzwolenie od Prawa, także ten, kto umiera z Chrystusem ( $\mathrm{Rz}$ 6,5-6), zostaje usprawiedliwiony / uwolniony od grzechu, jako że został ostatecznie wyzwo-

33 A. Pitta, Lettera ai Romani, s. 227.

34 S. Agersnap, Baptism and the New Life. A Study of Romans 6:1-14, Aarhus 1999, s. 322 . 
lony spod jego władzy ${ }^{35}$. Śmierć pozostaje w ścisłym związku z usprawiedliwieniem. Czy jednak znaczenie czasownika dikaioō ma tu takie znaczenie jak we wszystkich innych tekstach Listu do Rzymian? Kontekst zdaje się wskazywać na znaczenie „być wyzwolonym” (por. Syr 26,29; Dz 13,38-39) ${ }^{36}$. Jednak uwzględniając dotychczasowe wypowiedzi Apostoła, należy uznać, że chodzi o znaczenie „być usprawiedliwionym, otrzymać odpuszczenie” grzechów, które jednak nie są rozumiane jako wykroczenia przeciw Prawu, lecz raczej jako występek przeciw woli Boga. Ten więc, kto umarł, byłby wolny od instrumentu, dzięki któremu mógł dopuszczać się grzechów, a „grzeszne ciało”, w ten sposób pozostaje bez grzechu. Został zatem wyzwolony z ciała fizycznego, posiadającego skłonność do grzechu. W obu przypadkach zmienia się sytuacja człowieka. W chrzcie, na sposób śmierci, został położony kres dawnej sytuacji człowieka i została zainicjowana nowa sytuacja ${ }^{37}$. W tym więc kontekście usprawiedliwienie byłoby właśnie uwolnieniem od instrumentu, jakim jest ciało podległe grzechowi.

Śmierć daje wyzwolenie od ciała, jednak śmierć grzechowi, czyli wiara i przyjęcie chrztu nie dają jeszcze gwarancji zbawienia. Konieczny jest wysiłek oddawania siebie na służbę sprawiedliwości Boga: „Nie oddawajcie też członków waszych jako oręża nieprawości dla grzechu, ale oddajecie siebie samych Bogu, jako wskrzeszonych z martwych do życia i członki wasze jako oręż sprawiedliwości dla Boga (dikaiosynēs tō(i) Theō(i))" (Rz 6,13). Cała wypowiedź tego wersetu, ułożonego w formie antytetycznej, wiąże się z pojęciem Bożej sprawiedliwości. Wskazany został jej bezpośredni związek ze stanem chrześcijanina, który przez chrzest został wyzwolony z niewoli grzechu, aby się oddać na wyłączną służbę Bogu. Niewątpliwie Pawłowi w tym kontekście chodzi o sprawiedliwość w znaczeniu sądowym, jako dar pochodzący od Boga ${ }^{38}$. Istnieje wyraźny kontrast pomiędzy „nieprawością” (adikia), która skutkuje trwaniem w grzechu, a „sprawiedliwością” (dikaiosynē), która wiąże się z ciągłą walką z grzechem.

\subsection{Obdarzenie chwałą}

Argumentacja rozwinięta w 8,29-30 stanowi wyjaśnienie tezy postawionej w 8,28: „Wiemy zaś, że tym, którzy miłują Boga, wszystko służy ku dobremu;

35 R. Penna, Lettera ai Romani, s. 437.

36 S. Witkowski, Współukrzyżowani z Chrystusem i wolni od mocy grzechu (Rz 6,1-14), s. 111.

37 Por. J.A. Fitzmyer, Lettera ai Romani, s. 521.

38 R. Penna, Lettera ai Romani, s. 449-450. 
tym, którzy są powołani według Jego postanowienia”. Kolejne jej fazy rozwijają się w porządku klimaktycznym, a wszystko zmierza do obdarzenia chwałą: „Tych bowiem, których wcześniej poznał, tych też przeznaczył, aby się stali podobni do obrazu Jego Syna, aby był On pierworodnym między wielu braćmi. Tych zaś, których przeznaczył, tych też powołał, a których powołał, tych też usprawiedliwił (edikaiōsen), a których usprawiedliwił (edikaiōsen), tych też obdarzył chwałą" (8,29-30). Skupmy się na ostatniej fazie argumentacji, w której mowa jest o tym, że usprawiedliwienie skutkuje obdarzeniem chwałą: hous de edikaiōsen, toutous kai ediksasen. Zbawczy plan Boga zakładał wcześniejsze poznanie (proegnō), uprzednienie przeznaczenie (proōrisen), powołanie (ekalesen) i usprawiedliwienie (edikaiōsen), aby ostatecznie mogło dojść do osiągnięcia ostatecznego celu, czyli ubóstwienia, rzeczywistego przeznaczenia wszystkich, którzy uwierzyli w Chrystusa Jezusa (por. 1 Tes 2,12). Takie jest bowiem znaczenie czasownika edoksasen. Chwała Boża bowiem w Starym Testamencie bardzo często była synonimem samego Boga. Obdarowanie chwałą Boga, oznaczało posiadanie samego Boga, udział w Jego życiu ${ }^{39}$. Kiedy jednak ta chwała stanie się naszym udziałem, już teraz czy dopiero w wieczności? Bez wątpienia udział w niej „raz na zawsze” (Rz 6,10) jest owocem męki, śmierci i zmartwychwstania Chrystusa. Chwała ta „zostanie objawiona w nas” (Rz 8,18), a jest gwarantowana decyzją samego Boga ${ }^{40}$. Udział w niej (edoksasen) należałoby raczej rozszerzyć na aktualne doświadczenie, a nie tylko na antycypowanie przyszłej chwały ${ }^{41}$.

Aktualne doświadczenie, antycypacja przyszłej chwały związana jest ze stanem chrześcijanina, który uwierzył i przyjął chrzest. Dlatego też Paweł tak pisze na temat wybranych: „Kto będzie oskarżał wybranych Boga (eklektōn Theou)? Bóg, Ten, który usprawiedliwia (ho dikaiōn)" (Rz 8,33). Użyte tu określenie ho dikaiōn wskazuje nie tyle na atrybut Boga, ile na podmiot usprawiedliwienia, którym jest On sam. Użyte słownictwo sądownicze nawiązuje do trybunału, przed którym musi stanąć każdy człowiek w czasach eschatologicznych. Bóg, który jest źródłem usprawiedliwienia, nie dopuści do tego, aby ktokolwiek mógł wysunąć oskarżenie wobec tych, którzy dostąpili usprawiedliwienia i zostali wyłączeni spod działania eschatologicznego gniewu ${ }^{42}$.

Pisałem o tym już w: S. Stasiak, Komentarz teologiczno-pastoralny, s. 322.

J.A. Fitzmyer, Lettera ai Romani, s. 626.

41

H. Schlier, La lettera ai Romani, s. 451-452.

42

A. Pitta, Lettera ai Romani, s. 317. 


\subsection{Czym jest królestwo Boże?}

Kolejnym skutkiem usprawiedliwienia jest królestwo Boże. Paweł stwierdza, że ono jest wręcz sprawiedliwością, pokojem i radością: „Królestwo Boga przecież nie jest pokarmem i napojem, ale sprawiedliwością (dikaiosynē), pokojem (eirēnē) i radością w Duchu Świętym (chara en pneumati hagiō(i))" (Rz 14,17). Wprawdzie głównym tematem tej sekcji jest sprawa gorszenia słabych przez spożywanie nieodpowiednich posiłków, to jednak w tym właśnie kontekście Paweł pisze na temat atrybutów królestwa Bożego. Jednym z nich jest „sprawiedliwość" (dikaiosynē), o której Apostoł pisał bardzo szeroko w całym liście. Dotychczas rzeczywistość ta była ukazana jako przejaw Bożego miłosierdzia objawionego w Chrystusie wobec grzesznika ${ }^{43}$. Tu po raz ostatni w liście pojawia się to pojęcie. Może to mieć znaczący wpływ na rozumienie pozostałych dwóch atrybutów królestwa Bożego - pokoju i radości w Duchu Świętym. Zatem sprawiedliwość, to nie jest jedynie dobre postępowanie, lecz darowana moc Boga, pokój otwarciem się na drugiego, radość znalezienia się pod otwartym niebem. Nie chodzi tu o jakieś sentymenty, lecz o sytuacje, które są charakterystyczne dla inauguracji królestwa Bożego i wspólnoty chrześcijańskiej ${ }^{44}$. Sprawiedliwość zatem charakteryzuje członków nowego ludu Bożego, Kościoła Jezusa Chrystusa.

\section{Uporczywe trzymanie się swojej sprawiedliwości}

Błąd człowieka polega nie tylko na tym, że wybiera życie w grzechu, mimo wyzwolenia z niego przez wiarę w Chrystusa i przyjęty chrzest. Problem również w tym, że człowiek może wybierać własną sprawiedliwość w miejsce Bożej sprawiedliwości. Paweł tak pisał na temat swoich współplemieńców: „Nie znając bowiem sprawiedliwości Bożej (tēn tou Theou dikaiosynēn) i dążąc do ustanowienia własnej sprawiedliwości (tēn idian dikaiosynēn), nie podporządkowali się sprawiedliwości Bożej (tēe(i) dikaiosynē(i) tou Theou), ponieważ końcem Prawa jest Chrystus, dla sprawiedliwości każdego, kto wierzy (eis dikaiosynēn panti tō(i) pisteuonti)" (Rz 10,3-4). W tym miejscu nie będziemy zajmowali się wszystkimi wystąpieniami rzeczownika he dikaiosynēe, ponieważ temu zagadnieniu poświęciliśmy dotychczasowe poszukiwania. Skupimy się jedynie na przeciwstawieniu się Izraelitów Bożej sprawiedliwości, co zostało przed-

\footnotetext{
43 R. Penna, Lettera ai Romani, s. 976.

44 Tak przedstawił to zagadnienie już przez laty E. Käsemann, Commentary on Romans, s. 377.
} 
stawione na dwa sposoby: negatywny (agnoountes tèn tou Theou dikaiosynēn) i pozytywny (tēn idian dikaiosynēn dzètountes). Działanie o charakterze negatywnym, wyrażone za pomocą imiesłowu przyczynowego agnoountes, wskazuje na postawę wielu Izraelitów, którzy uznali, że usprawiedliwienie można osiągnąć na podstawie uczynków wymaganych przez Prawo, a nie przez wiarę w Jezusa Chrystusa, i dlatego odrzucili Bożą sprawiedliwość, która objawia się w Ewangelii. Działanie o charakterze pozytywnym zostało oddane imiesłowem dzētountes, również o znaczeniu przyczynowym. Brak podporządkowania się sprawiedliwości Bożej znajduje swój powód w dążeniu do ustanowienia własnej sprawiedliwości opartej na uczynkach wymaganych przez Prawo. Konsekwencją obu działań jest brak podporządkowania się sprawiedliwości Bożej, czyli temu atrybutowi Boga, który został objawiony w Ewangelii co do Chrystusa i wiary w Niego. Błąd wyznawców judaizmu polegał więc na tym, że odrzucając wiarę w Jezusa Chrystusa i Jego Ewangelię, wybrali „własną sprawiedliwość”, o której wartości byli absolutnie przekonani. A była nią wierność przepisom Prawa Mojżesza nie tyle w sensie społecznym, ile etycznym ${ }^{45}$. Człowiek zatem pozostaje wolny nawet w obliczu Bożej sprawiedliwości, która wprowadza go na drogę wiary w Jezusa Chrystusa i orędzia Jego Ewangelii. Może nie tylko je odrzucić i wybrać drogę grzechu, lecz także wybrać własną sprawiedliwość, podobnie jak uczynili to Izraelici.

\section{Zakończenie}

Opierając się na występowaniu terminów hē dikaiosynē i dikaioō w Liście do Rzymian, odkryliśmy, że teksty je zawierające tworzą interesujący układ. Pozwolił on nam na uporządkowanie materiału w ten sposób, że wyłoniła się dość uporządkowana wiedza na temat zarówno Bożej sprawiedliwości, jak i usprawiedliwienia, którego dostępuje chrześcijanin dzięki wierze w Jezusa Chrystusa. Przede wszystkim Paweł miał doskonałą świadomość jednej z podstawowych zasad judaizmu, którą przytoczył w Rz 2,13: „ci, którzy praktykują Prawo, zostaną usprawiedliwieni”. Jednak z całą pewnością nie identyfikował się z tym założeniem, a jedynie przytoczył tekst Starego Testamentu, aby następnie wykazać, że rzecz ma się zupełnie inaczej - człowiek zyskuje usprawiedliwienie przez wiarę, a na wzór Abrahama. Zagadnienie to dość obszernie omawia Apostoł w kolejnych rozdziałach listu. Wychodzi on od stwierdzenia faktu objawienia Bożej sprawiedliwości $(1,17)$. Ona staje się jeszcze bardziej jawna na tle naszej niesprawiedliwości ( $\mathrm{Rz} 3,3-5)$. Ma nadto wymiar historiozbawczy,

45 D. Ortlund, 'Zeal without knowledge', s. 31-32. 
prowadzący do sprawiedliwości każdego wierzącego. Boża sprawiedliwość skutkuje więc działaniami zbawczymi na rzecz człowieka, a podjął je Chrystus, umierając na krzyżu i zmartwychwstając. Wykład na ten temat Apostoł przeprowadził w 3,21-31, którego najkrótszym wnioskiem, a zarazem dowodzoną tezą jest to, że człowiek osiąga usprawiedliwienie z wiary w Jezusa Chrystusa, a nie na podstawie pełnienia uczynków wymaganych przez Prawo. Wszyscy mają w nim udział nie tylko Żydzi, dla których wiara jest continuum przez monoteizm religijny i przez udział w błogosławieństwie Boga, ale i poganie, na których wiara jest udziałem w zbawczej śmierci Chrystusa. Wzorem wiary, która skutkuje usprawiedliwieniem, jest Abraham, on bowiem uwierzył i to zostało mu policzone ku usprawiedliwieniu ( $\mathrm{Rz} 4,2-7)$. Odnotowaliśmy również, że usprawiedliwienie wierzącego niesie ze sobą bardzo konkretne skutki: trwanie w pokoju (Rz 5,1-2), zachowanie od gniewu Bożego (Rz 5,9), wezwanie do unikania grzechów (Rz 6,7), obdarzenie chwałą (Rz 8,29-30.33). Mimo tak wielkich darów człowiek może wybrać drogę własnej sprawiedliwości, odrzucając Bożą sprawiedliwość, podobnie jak Izraelici wybrali drogę pełnienia uczynków wymaganych przez Prawo, a odrzucili wiarę w Jezusa Chrystusa i Jego Ewangelię.

\section{Bibliografia}

Agersnap S., Baptism and the New Life. A Study of Romans 6:1-14, Aarhus 1999.

Bailey D.P., Jesus as the Mercy Seat. The Semantics and Theology of Paul's Use of hilasterion in Romans 3:25, Tyndale Bulletin 51/1(2000), 155-158.

Basta P., Gezerah Shawah. Storia, forme e metodi dell'analogia biblica, Roma 2006.

Burk D., The righteousness of God (Dikaiosunē Theou) and Verbal Genitives. A Grammatical Clarification, Journal for the Study of the New Testament 34/4(2012), 346-360.

Ekem J.D.K., A Dialogical Exegesis of Romans 3.25a, Journal for the Study of the New Testament 30/1(2007), 75-93.

Fitzmyer J.A., Lettera ai Romani. Commentario critico-teologico (trad. E. Gatti), Casale Monferrato 1999.

Holmes C.T., Utterly Incapacitated. The Neglected Meaning of $\pi \dot{\alpha} \rho \varepsilon \sigma \iota \varsigma$ in Romans 3:25, Novum Testamentum 55/4(2013), 349-366.

Käsemann E., Commentary on Romans (trans. G.W. Bromiley), Grand Rapids 1980.

Lambrecht J., Why is Boasting Excluded? A Note on Rom 3:27 and 4:2, Ephemerides Theologicae Lovanienses 61/4(1985), 365-369.

Lambrecht J., Thompson R.W., Justification by Faith. The Implications of Romans 3:27-31, Wilmington 1989. 
Ortlund D., 'Zeal without knowledge'. For What Did Paul Criticize His Fellow Jews in Romans 10:2-3?, The Westminster Theological Journal 73/1(2011), 23-37.

Penna R., Lettera ai Romani, Bologna 2010.

Pitta A., Lettera ai Romani. Nuova versione, introduzione e commento, Milano 2001.

Romaniuk K., List do Rzymian. Wstęp, przekład z oryginału, komentarz, Poznań-Warszawa 1978.

Schreiber S., Das Weihegeschenk Gottes: eine Deutung des Todes Jesu in Röm 3,25, ZNW 97(2006), 88-110.

Schlier H., La lettera ai Romani. Testo Greco, traduzione e commento (trad. R. Favero, G. Torti), Brescia 1982.

Siwecki L., Dobre uczynki usprawiedliwionego. Wartość zasługi, Ateneum Kapłańskie 581/1(2006), 84-98.

Stasiak S., Komentarz teologiczno-pastoralny do Biblii Tysiaclecia. Nowy Testament. Dzieje Apostolskie, List do Rzymian, 1-2 List do Koryntian, List do Galatów, Poznań 2014.

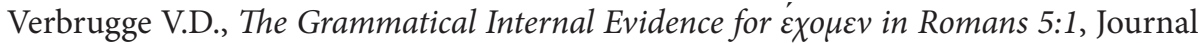
of the Evangelical Theological Society 54/3(2011), 559-572.

Weiss A., Christus Jesus als Weihegeschenk oder Sühnemal? Anmerkungen zu einer neueren Deutung von hilasterion (Röm 3,25) samt einer Liste der epigraphischen Belege, Zeitschrift für die Neutestamentliche Wissenschaft und die Kunde der Älteren Kirche 105/2(2014), 294-302.

Westerholm S., Justification by Faith is the Answer. What is the Question?, Concordia Theological Quarterly 70/3-4(2006), 197-217.

Wilson M.W., Hilasterion and Imperial Ideology. A New Reading of Romans 3:25, Hervormde Teologiese Studies 73/3(2017), 1-9.

Witkowski S., Współukrzyżowani z Chrystusem i wolni od mocy grzechu (Rz 6,1-14), Ruch Biblijny i Liturgiczny 62/2(2009), 103-116.

Wright N.T., Justification by (Covenant) Faith to the (Covenantal) Doers. Romans 2 within the Argument of the Letter, The Covenant Quarterly, 72/3(2014), 95-108. 